\title{
Differential Scanning Calorimetry (DSC) and Thermogravimetric Analysis (TGA) of Wood polymer nanocomposites
}

\author{
Md. Rezaur Rahman ${ }^{1, a}$, Sinin Hamdan², Josephine Lai Chang Hui ${ }^{1}$ \\ ${ }^{1}$ Department of Chemical Engineering and Energy Sustainability, Faculty of Engineering, Universiti Malaysia Sarawak, 94300, Kota \\ Samarahan, Sarawak, Malaysia \\ ${ }^{2}$ Department of Mechanical and Manufacturing Engineering, Faculty of Engineering, Universiti Malaysia Sarawak, 94300, Kota Samarahan, \\ Sarawak, Malaysia
}

\begin{abstract}
This study evaluates the thermal property of clay dispersed Styrene-co-Glycidal Methacrylate impregnated wood polymer nanocomposite (WPNC). The WPNC was characterized by FTIR, TGA and DSC methods. FT-IR result showed that the absorbance of wave number at $1730 \mathrm{~cm}-1$, increased for clay dispersed Styrene-co-Glycidyl Methacrylate wood polymer nanocomposite (ST-co-GMA-clay-WPNC). From TGA, ST-co-GMA-clay-WPNC showed better thermal stability at the temperature below $450 \mathrm{oC}$. The final weights of ST-co-GMA-clay-WPNC and ST-Clay-WPNC, between 420 and $700 \mathrm{oC}$, were significantly less than the raw wood. When the temperature was below $450 \mathrm{oC}$, nanoclay-incorporated surface modified wood composites showed enhanced higher thermal properties compared with those without nanoclay. From DSC, the degradation enthalpy at around $360 \mathrm{oC}$ of ST-co-GMA-ClayWPNC was the highest.
\end{abstract}

\section{INTRODUCTION}

Wood is one of the most widely used construction materials due to being unique renewable, having good physical and mechanical properties, aesthetic appearance, environmental and health aspects [1-3]. Wood has increased attention by the material researcher for replacing synthetic plastic materials which is not renewable and eco-friendly [4-6].

The constituents of wood are basically a series of tubular fibers or cells cemented together. Cellulose is highly responsible for wood strength for its linear orientation and a high degree of polymerization in wood. Hemicelluloses act as a coupling agent to bind noncrystalline hydrophilic cellulose and amorphous hydrophobic lignin. Cellulose, hemicellulose, and lignin are mainly responsible for mechanical properties of wood. The macromolecule of cellulose is formed by covalent bond which is resistance for tensile stress and hydrogen bonds within the cellulose provide rigidity by transferring stress. At high humidity, wood is dimensionally unstable and susceptible to termites' attack for taking water from the environment in its cell walls and cavities due to its hydrophilic and capillarity properties [7]. At low humidity environment, wood desorbs water to shrinkage. Hygroscopic and dimensionally unstable properties restrict the use of wood. In outdoor applications, wood suffers from the photodegradation process [8]. Wood also disclosures when uses indoor by oxidation of lignin, albeit with lower intensity [9]. However, the carbon based cellulosic material, wood is thermally unstable when it is subjected to heat in suitable conditions [10]. To overcome the above drawback, modified wood such as wood plastic composites, and wood composites are used as wood materials instead of conventional wood [11, 3]. For decreasing hydrophilicity and fungal attack of wood, various chemical treatments have been introduced such as acetylation, benzylation, silane or maleic anhydride grafting, etc. In all these chemicals react with $-\mathrm{OH}$ groups of wood [12].

When wood is subjected to heat flow, there produces pyrolysis products which can also reduce or increase heat production. The mechanism of thermal stability property of wood composite depends on its fire-retardant chemicals and chemical modification of wood cell wall [13]. Fire retardant chemicals in pyrolysis reactions increase the formation of char and water, and therefore reduce the effective heat of combustion and the yield of the flammable gases [14-15]. Phosphoric acid is one of the most uses fire retardant chemicals to reduce the number of volatiles and to increase the amount of residual char [16, 17]. $\mathrm{Al}(\mathrm{OH})_{3}$ and $\mathrm{Mg}(\mathrm{OH})_{2}$ are used as heat retardant materials for their endothermic property and their dehydration property dilute the combustible fuels and oxygen [18]. Silicates as heat retardants in wood composite make silica carbon compound which creates a barrier, but this residue is structurally very weak $[19,20]$. Montmorillonite clays, $\mathrm{TiO}_{2}, \mathrm{Sb}_{2} \mathrm{O}_{3}$, aluminosilicates, vermiculite, perlite and organoclays are used as heat retardants material to increase the thermal stability of wood [21-23]. Chemically modified and nanofiller impregnated wood gain mechanical and thermal properties [24].

For evaluating the effectiveness of thermal property of treated wood various methods have been developed such as thermal analysis, tunnel flame-spread tests, critical oxygen index tests, smoke production tests, fire tube test, cone calorimeter, heat release rate, toxicity and analysis of solid residue or gaseous products of thermal decomposition [14, 15]. Among these methods, differential scanning calorimetry and thermogravimetry are simple methods for evaluating the pyrolysis and flame retardants under air or inert gas flow.

The present study investigates differential Scanning Calorimetry (DSC) and thermogravimetric (TGA) properties of clay dispersed Styrene-co-Glycidyl

\footnotetext{
a Corresponding author: rmrezaur@feng.unimas.my
} 
Methacrylate (St-co-GMA-clay) wood polymer nanocomposite (WPNC).

\section{METHODOLOGY}

\subsection{Materials}

Five specimens were chosen for this study. This wood was impregnated by Styrene (ST) (Avantor), Glycidyl methacrylate (GMA) (Aldrich) and Montmorillonite (MMT) nanoclay (Nanomer $\left.{ }^{\mathrm{R}} 1.28 \mathrm{E}\right)$, modified with $25-30$ wt. \% trimeth stearyl ammonium (Aldrich). Benzoyl peroxide (Merck Schuchardt OHG) was used in the system as a catalyst to increase the reaction rate by free radical mechanism.

\subsection{Methods}

\subsubsection{Specimen Preparations}

Kumpang tree was cut into three bolts of $1.2 \mathrm{~m}$ long. Each bolt was quarter-sawn to produce planks of $4 \mathrm{~cm}$ thickness and subsequently conditioned to air drying in a room with relative humidity of $60 \%$ and ambient temperature of around $25^{\circ} \mathrm{C}$ for one month prior to testing. The planks were ripped and machined to oven dry.

\subsubsection{Preparation of WPNCs}

Oven-dried specimens were impregnated with $500 \mathrm{~mL}$ of styrene (St), a mixture of $500 \mathrm{~mL}$ of styrene with $10 \mathrm{gm}$ MMT, a mixture of $500 \mathrm{~mL}$ of styrene with glycidyl methacrylate (1:1 ratio), and $10 \mathrm{gm}$ MMT. The fourdifferent solution mixture were used to impregnate the wood specimens. The wood specimens were then separately placed in an impregnation vacuum chamber of $75 \mathrm{~mm}(\mathrm{Hg})$ for $30 \mathrm{~min}$. In each system, approximately $10 \mathrm{gm}$ of benzoyl peroxide was added as the initiator. These wood composites were then removed from the chamber, and the excess chemicals were wiped off. Specimens wrapped with aluminum foil were placed in an oven for $24 \mathrm{~h}$ at $105{ }^{\circ} \mathrm{C}$ for polymerization to take place.

Table 1. Preparation of WPCs and WPNCs.

\begin{tabular}{|l|l|l|l|}
\hline & $\begin{array}{l}\text { Amount } \\
\text { of } \\
\text { styrene } \\
(\mathbf{m L})\end{array}$ & $\begin{array}{l}\text { Amount } \\
\text { of GMA } \\
(\mathbf{m L})\end{array}$ & $\begin{array}{l}\text { Amount } \\
\text { (g) } \\
\text { of clay } \\
\text { type } \\
(\mathbf{1 . 2 8 E})\end{array}$ \\
\hline Raw wood (RW) & & & \\
\hline RW & 500 & 500 & \\
\hline RW & 500 & & 10 \\
\hline RW & 500 & 500 & 10 \\
\hline RW & 500 & & \\
\hline
\end{tabular}

\subsection{Microstructural Analysis}

\subsubsection{Fourier Transform Infrared Spectroscopy (FT-IR)}

The infrared spectra of the monomer systems were recorded on a Shimadzu IRAffinity-1. The transmittance range of the scan was 600 to $4000 \mathrm{~cm}^{-1}$ [13-14].

\subsubsection{Thermogravimetric Analysis (TGA)}

Thermogravimetric analysis (TGA) measurements were carried out on 5-10 $\mathrm{mg}$ of each sample at a heating rate of $10^{\circ} \mathrm{C} / \mathrm{min}$ in a nitrogen atmosphere using a Thermogravimetric Analyzer (TA Instrument SDT Q600). Raw wood, wood polymer composites (WPCs) and WPNCs were subjected to TGA in high purity nitrogen under a constant flow rate of $5 \mathrm{~mL} / \mathrm{min}$. Thermal decomposition of each sample occurred in a programmed temperature range of $50-600^{\circ} \mathrm{C}$. The continuous weight loss and temperature were recorded and analyzed.

\subsubsection{Differential Scanning Calorimetry (DSC)}

DSC was performed with a TGA/DSC1 STAR System, Mettler Toledo thermal analyzer according to ASTM D3418. The thermal analyses were done in a nitrogen gas atmosphere with a flow rate of $30 \mathrm{~mL} \mathrm{~min}^{-1}$ at a heating rate of $10^{\circ} \mathrm{C} \mathrm{min}^{-1}$ from $50^{\circ} \mathrm{C}$ to $800^{\circ} \mathrm{C}$. The weight of the samples was maintained at about $10 \mathrm{mg}$.

\subsection{RESULTS AND DISCUSSION}

\subsection{Fourier Transform Infrared Spectroscopy (FT-IR) Analysis}

The FTIR spectra of a) ST-co-GMA-WPC, b) ST-coGMA-clay-WPNC, c) ST-Clay-WPNC d) ST-WPC and e) RW are presented in Figure 1. The peak from 4000 to $3000 \mathrm{~cm}^{-1}$ corresponds to stretching of $\mathrm{H}$-bonds in $-\mathrm{OH}$ groups and $\mathrm{C}-\mathrm{H}$ stretching in methyl and methylene groups range from 3000 to $2800 \mathrm{~cm}^{-}$[13]. The intensity near $1505 \mathrm{~cm}^{-1}$ (for aromatic double bond) was higher for ST impregnated wood compare to raw wood. This was due to increase in the concentration of aromatic group in ST-WPC. The IR spectrum intensity of ST-WPC, exhibited peak intensity above $3000 \mathrm{~cm}^{-1}$, for -OH group, was lower than raw wood due to the removal of free water from the wood lumen by ST. The peak intensity of -OH group for ST-co-GMA impregnated wood was lower than the ST impregnated wood because of covalent bond between $-\mathrm{OH}$ of wood and Glycidyl group of GMA. It can be attributed that ST-co-GMA performs better filler than ST alone.

In the case of ST-co-GMA-clay-WPNC composite, the wave number is above $3000 \mathrm{~cm}^{-1}$, the peak intensity does not drop compared to raw wood. It increases due to the clay ST-co- GMA polymer system which removes less - $\mathrm{OH}$ of cellulose, hemicellulose and water from wood lumen. The $-\mathrm{OH}$ groups of montmorillonites in composite gives bending absorption near $840 \mathrm{~cm}^{-1}$ for $\mathrm{MgAl}(\mathrm{OH})$ [25]. The absorption peak near $905 \mathrm{~cm}^{-1}$ is more intense in ST-co-GMA-clay-WPNC system than other ones. The peak intensity near $1730 \mathrm{~cm}^{-1}$ increases due to increasing carbonyl group concentration in the composite compared to the raw wood. The addition of 
montmorillonite in ST-co-GMA-clay-WPNC system, the carbonyl peak intensity is higher than ST-co-GMA system. This is due to the copolymerization between ST and GMA for the exfoliation of montmorillonite in the wood.

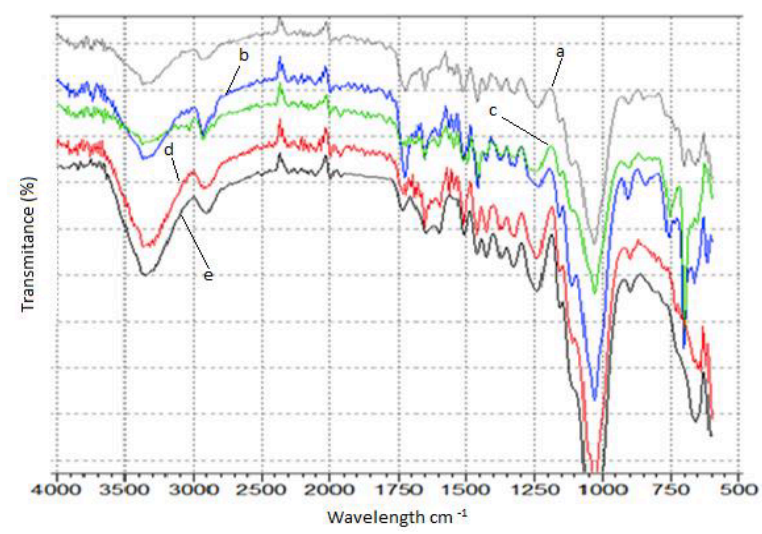

Figure 1. FTIR of a) ST-co-GMA-WPC, b) ST-coGMA-clay-WPNC, c) ST-Clay-WPNC d) ST-WPC, e) RW.

\subsection{Thermogravimetric analysis (TGA)}

WPC, ST-co-GMA-clay-WPNC and ST-Clay-WPNC are shown in Figure 2. Figure 2 shows that the thermal stability below $420^{\circ} \mathrm{C}$ of clay dispersed WPNCS increases significantly compared with the raw wood and WPCs. Three steps in the thermal decomposition of raw wood, WPCs and WPNCs could be observed. The first step degradation occurred between $70^{\circ} \mathrm{C}$ to $110^{\circ} \mathrm{C}$ while the second step degradation occurred above $200^{\circ} \mathrm{C}$ for all the raw wood and composites. The first step weight loss was associated with the evaporation of absorbed moisture from the samples $[26,13]$. There are three different types of water, such as free water, loosely bonded water and chemically bonded water, in wood. As a consequence, the loss of water, as recorded by the thermo gravimetric curve, is the result of the overlapping of three different processes in which the three types of water are lost [27]. The initial weight loss of the samples below $110^{\circ} \mathrm{C}$ was the lowest for ST-co-GMA-clay-WPNC compared to RW, ST-Clay-WPNC, ST-WPC and ST-co-GMA-WPC respectively. This is due to GMA forms covalent bond with - $\mathrm{OH}$ groups of wood cell wall and surface modified MMT fills the cavity of wood cell wall. Second-step degradation between $250-420^{\circ} \mathrm{C}$, ST-co-GMA-WPC, STco-GMA-clay-WPNC and ST-Clay-WPNC were more thermally stable compared to raw wood and ST-WPC. This is due to exfoliated or intercalated MMT in ST-coGMA-Clay-WPNC and ST-Clay-WPNC reduces the surface energy of raw wood polymer. Well-distributed MMT layers could prevent the passage of volatile decomposed product throughout the composite. Thus the addition of MMT improved the thermal stability for second stage degradation of nanocomposites [28]. In this second stage, hemicellulose, cellulose and lignin degrade between $200^{\circ} \mathrm{C}-500^{\circ} \mathrm{C}[29,30]$. In this stage, among the composites, ST-WPC showed the lowest thermal stability because ST does not make any bond with wood cell wall.
The final weights, between 420 and $700^{\circ} \mathrm{C}$, of ST-coGMA-clay-WPNC and ST-Clay-WPNC were significantly less than the raw wood due to the dehydroxylation of the aluminosilicate [31].

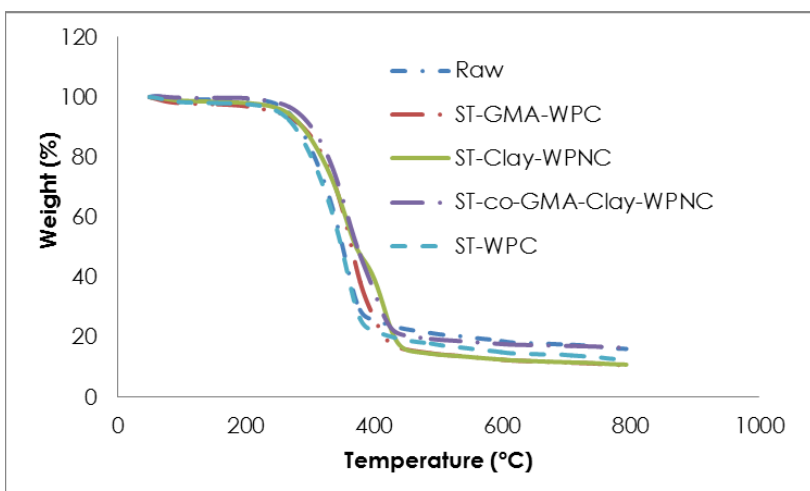

Figure 2. TGA of a) ST-co-GMA-WPC, b) ST-co-GMAclay-WPNC, c) ST-Clay-WPNC d) ST-WPC, e) RW.

\subsection{Differential Scanning Calorimetric Analysis}

DSC analysis is carried out to determine the thermal energy released or absorbed via chemical reactions of the raw wood, WPCs and WPNCs constituents during heating, which lead to the exothermic and endothermic reactions. Endothermic reactions provide information on sample melting, phase transitions, evaporation, dehydration, and pyrolysis. Exothermic reactions provide information on crystallization, oxidation, combustion, decomposition, and chemical reactions [32, 33]. Figure. 3 showed the DSC curves of the raw wood, WPCs and WPNCs. It was seen that the composites exhibit five patterns of heat flow. First, a broad endothermic peak observed around $71^{\circ} \mathrm{C}$ for raw wood and WPCs and WPNCs, which corresponds to the evaporation of absorbed water by the raw wood and wood composites. The treated wood composites have focused on the reduction of absorbed water by the wood cell wall in this study. Thus, the water loss peak of WPNCs shifted to higher temperature: $72^{\circ} \mathrm{C}$ for the raw wood and $78^{\circ} \mathrm{C}$ for WPNCs. And it became weak for WPNCs compared to raw wood. This tendency of releasing water at a higher temperature in the treated composite with and without clay could be due to the improved wetting property, resulting in the better interfacial interaction among wood cell wall, filler polymer and clay [21]. The glass transition of wood and its composites cannot be easily detected due to the interference of water evaporation in wood and the presence of unreacted GMA [34]. Second, the very strong endothermic peak observed around $362^{\circ} \mathrm{C}$ indicates the degradation of cellulose, leading to char formation [21]. Around $360^{\circ} \mathrm{C}$, the degradation enthalpy $1463.82 \mathrm{~J} / \mathrm{g}$ of ST-co-GMA-Clay-WPNC was higher compared to other composite system and raw wood. This is due to formation of better interfacial adhesion in STco-GMA-Clay-WPNC than the other composite systems and raw wood. Third, exothermic combustion of lignin and hemicellulose for raw wood, ST-WPC and ST-ClayWNC occurred around $380^{\circ} \mathrm{C}$. This combustion for STco-GMA-WPC and ST-co-GMA-Clay-WPNC do not 
appreciably occurred due to better interfacial bonding among wood cell wall, ST-co-GMA and MMT. Fourth a broad endothermic peak observed around $400-418^{\circ} \mathrm{C}$ for WPNCs due to the breaking of forces between wood cell wall and MMT.

Fifth, exothermic peak observed for ST-Clay-WNC, ST-co-GMA-WPC and ST-co-GMA-WPC at $435^{\circ} \mathrm{C}$, $445^{\circ} \mathrm{C}$ and $420^{\circ} \mathrm{C}$ respectively. This is due to combustion of lignin, cellulose and hemicellulose that take part in the reaction with wood cell wall. Around $430^{\circ} \mathrm{C}$, there is no exothermic peak for raw wood and ST-WPC because these two samples were completely combusted at $380^{\circ} \mathrm{C}$ for poor adhesion.

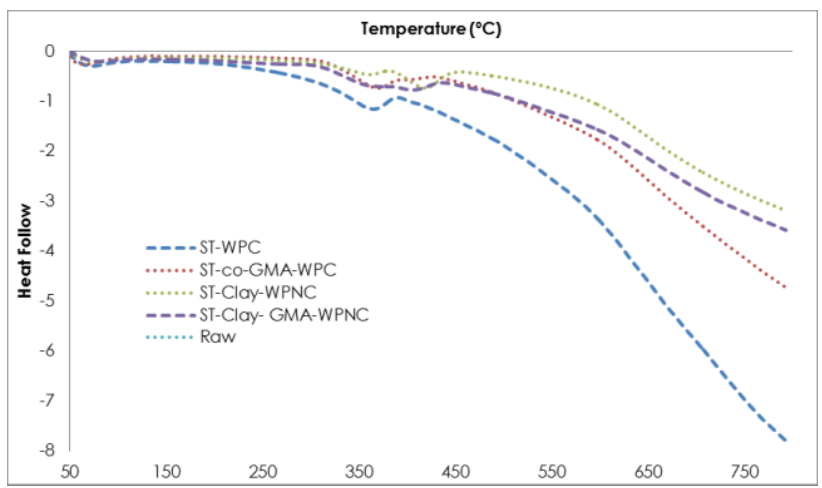

Figure 3. DSC of a) ST-co-GMA-WPC, b) ST-co-GMAclay-WPNC, c) ST-Clay-WPNC d) ST-WPC, e) RW.

\section{CONCLUSION}

1. In the present study, it is concluded that Kumpang wood were successfully impregnated by clay dispersed Styrene-co-Glycidyl Methacrylate (St-coGMA-clay) which is proved by FT-IR analysis.

2. The TGA result showed, around temperature 250$350^{\circ} \mathrm{C}$, WPNCs and ST-co-GMA-CWPC had higher thermal stability and char formation followed by STWPC and RW wood respectively. Above $350^{\circ} \mathrm{C}$, the final char weights of ST-co-GMA-clay-WPNC, STClay-WPNC and ST-WPC were significantly less than the raw wood.

3. From DSC result it can be concluded that around $360^{\circ} \mathrm{C}$, the degradation enthalpy $1463.82 \mathrm{~J} / \mathrm{g}$ of STco-GMA-Clay-WPNC was higher compared to other composite systems and raw wood. Around $380^{\circ} \mathrm{C}$ combustions for ST-co-GMA-WPC and ST-coGMA-Clay-WPNC do not appreciably occur. Forces between wood cell wall and MMT broke down around $400-418^{\circ} \mathrm{C}$. Exothermic peaks, around $430^{\circ} \mathrm{C}$, were observed only for ST-Clay-WNC, ST-coGMA-WPC and ST-co-GMA-WPC.

\section{Acknowledgement}

The authors would like to acknowledge the financial support from The authors would like to acknowledge the financial support from COERE Fund with Grant no. COERE/GRANT/2013/06.

\section{References}

1. A. Temiz, E.D. Gezer, U.C. Yildiz, S. Yildiz, Construct. Build. Mater. 22, 2165 (2008)

2. A.A. Klyosov, Wood-Plastic Composites (John Wiley and Sons, Inc., New Jersey, 2007)

3. Y. Cao, J. Lu, R. Huang, Y. Zhao, Y. Wu, BioRes. 6, 4696 (2011)

4. A.K. Mohanty, M. Misra, L.T. Drzal, Polym. Environ. 10, 19 (2002)

5. A.K. Bledzki, A.A. Mamun, O. Faruk, eXPRESS Polym. Lett. 1, 755 (2007)

6. M.R. Rahman, J.C.H. Lai, S. Hamdan, M.M. Rahman, M.F. Hossen, J. Appl. Polym. Sci. 132 (2015)

7. R.M. Rowell, Mater. Sci. Eng. 1, 29 (2006)

8. B.D. Mattos, P.H.G.D. Cademartori, T.V. Lourencon, D. Gatto, Int. Wood Prod. J. 5, 33 (2014)

9. W.C. Feist, N.S.H. David, Chemistry of weathering and protection (DC American Chemical Society, Washington, 1984)

10. M.K. Yalinkilic, Y. Imamura, M. Takahashi, Z. Demirci, Wood Fib. Sci. 30, 348 (1998)

11. S.T. Chang, H.T. Chang, Polym. Degrad. Stabil. 71, 261 (2001)

12. Y.J. Xie, C.A.S. Hill, D. Sun, Z. Jalaludin, Q. Wang, C. Mai, BioRes. 6, 2323 (2011)

13. M.R. Rahman, S. Hamdan, S.A. Ahmed, M.S. Islam, Z.A. Talib, W.F.W. Abdullah, M.S.C. Mat, J. Vinyl Addit. Technol. DOI 10.1002/vnl.20275

14. S.L. Levan H.C. Tran, Effects of dynamic aging (hydrolysis and condensation) behaviour of organofunctional silanes in the aqueous solution on their penetrability into the cell walls of wood Margaret. Madison, (Forest Products Research Society, WI, 1990)

15. H. Yunchu, Z. Peijang, Q. Songsheng, Holz. Roh. Werkstoff 58, 35 (2000)

16. E. Baysal, African J. Biotech. 10, 19255 (2011)

17. R.M. Rowell, The Chemistry of Solid Wood. Advances in Chemistry Series 207 (American Chemical Society, Washington, 1984)

18. M. Garcia, J. Hidalgo, I. Garmendia, J. García-Jaca Compos. Part A 40, 1772 (2009)

19. S.Y. Lu, I. Hamerton, Prog. Polym. Sci. 27, 1661 (2002)

20. B. Xu, J. Ding, L. Feng, Y. Ding F. Ge, Z. Cai, Surf. Coat. Technol. 262, 70 (2015)

21. E. Bozkurt, E. Kaya, M. Tanoglu, Compos. Sci. Technol. 67, 3394 (2007)

22. S. Zhang, A.R. Horrocks, Prog. Polym Sci. 28, 1520 (2003)

23. M.K. Chang, S.J. Li, K.S. Wu, A study of strength and thermal stability of Low-density polyethylene grafted maleic anhydride/montmorillonite nanocomposites (International Conference on Industrial Engineering and Operations Management Kuala Lumpur, Malaysia, 2011) 
24. S. Liodakis, D. Bakirtzis, A.P. Dimitrakopoulos, Thermochim. Acta 399, 31 (2003)

25. G. Sposito, Clay Clay Miner. 31, 9 (1983)

26. Z. Liu, Z. Jiang, B. Fei, X. Liu, BioRes. 8, 5014 (2013)

27. M. Forouharshad, M. Montazer, M.B. Moghadam, O. Saligheh, Thermochim. Acta 516, 29 (2011)

28. E. Pedro, Sánchez-Jiménez, A. Luis, PérezMaqueda, A. Perejón, J.M. Criado, J. Phy. Chem. C 116, 11797 (2012)

29. H.S. Kim, H.S. Yang, H.J. Kim, S. Kim, Thermochim. Acta 451, 181 (2006)

30. H. Yang, R. Yan H. Chen, D.H. Lee, C. Zheng, Fuel 86, 1781 (2007)

31. W. Xie, Z. Gao, W.P. Pan, D. Hunter, A. Singh, R. Vaia, Chem. Mater. 13, 2979 (2011)

32. R. Ball, A.C. McIntosh, J. Brindley, Phy. Chem. Chem. Phy. 1, 5035 (1999)

33. M.R. Rahman, M.F. Hossen, S. Hamdan, M.S. Islam, F.K. Liew, J.C.H. Lai, M.M. Rahman, Polym. Compos. (to be published)

34. S.K. Shaha, S. Dyuti, Q. Ahsan, M. Hasan, Adv. Mater. Res. 264-265, 1922 (2011) 